\title{
Psychological preparation for surgery: Verbal report of the drawing-story
}

\author{
Preparação psicológica para cirurgia: \\ relato verbal de desenho-história
}

\author{
Camilla Volpato BROERING \\ Maria Aparecida CREPALDI'
}

\begin{abstract}
Communicating with hospitalized children for invasive procedures usually takes place in a veiled and indirect way. This present study evaluated children's verbal report on the drawings that they produced in situations of the psychological preparation for surgery. The research was conducted with 30 participants divided into two preparation groups (verbal information and toys), users of a children's hospital who used the technique of drawing-story. There were three distinct stages: a) the child receives instruction on the design history and hears a story the day before the surgery; b) the psychological preparation, in both groups submitted to different programs of preparation, and c) reapplication of the technique of drawing-story, on the day of the surgery, after preparation. Both preparation programs were effective in reducing the pre-surgical stress, and evaluated the types of reactions, such as feelings of inferiority, abandonment and insecurity, regardless of the applied program.
\end{abstract}

Uniterms: Child psychology; Psychological preparation; Surgery in childhood.

\section{Resumo}

A comunicação com a criança hospitalizada para realização de procedimentos invasivos costuma ocorrer de maneira velada e indireta. Este estudo avaliou o relato verbal das crianças sobre os desenhos que produziram em situação de preparação psicológica pré-cirúrgica. Os participantes foram trinta crianças, divididos em dois grupos de preparação (informações verbais e brinquedos), usuários de um hospital infantil, e utilizou-se a técnica do desenho-história. A pesquisa foi realizada em três etapas: a) a criança recebe instrução sobre o desenho-história e ouve uma história, no dia anterior à cirurgia; b) preparação psicológica, nos grupos, submetidos a diferentes programas de preparação; c) reaplicação da instrução sobre o desenho-história, antes da cirurgia e após a preparação. Ambos os Programas de preparação foram eficazes na diminuição do estresse pré-cirúrgico e nos tipos de reações avaliados, tais como sentimento de inferioridade, abandono e insegurança, independentemente do programa aplicado.

Unitermos: Psicologia da criança; Preparação psicológica; Cirurgia na infância.

Hospitalization is a critical situation for any human being, and has special contours when it comes to an event in the life of a child, since it implies change in routine for the whole family (Faquinello, Higarashi \& Marcon, 2007). Regarding the importance that the child understand, in their own way, what is happening with

\section{$\boldsymbol{v} \nabla \boldsymbol{v}$}

1 Universidade Federal de Santa Catarina, Departamento de Psicologia, Laboratório de Psicologia da Família Saúde e Comunidade. Campus Universitário, Trindade, 88040-970, Florianópolis, SC, Brasil. Correspondência para/Correspondence to: C.V. BROERING. E-mail: <millavolbro@hotmail.com>.

Article based on the dissertation of the C.V. BROERING, intitled "Efeitos da preparação psicológica pré-cirúrgica em crianças a serem submetidas a cirurgias eletivas". Universidade Federal de Santa Catarina, 2008. 
their health, they are not always clearly explained about what is going to happen to them at the hospital. A study with hospitalized children from 5 to 11 years of age, victims of chronic diseases, showed that they are informed indirectly, either by listening to the physician talking with their parents or reading the facial expressions of adults (Gabarra \& Crepaldi, 2011).

There are studies that show that children in the process of undergoing surgeries benefit from some kind psychological preparation (Broering \& Crepaldi, 2008; Crepaldi \& Hackbarth, 2002; Salmon, 2006; Trinca, 2003; Uman, Chambers, McGrath \& Kisely, 2008). When planning this preparation it is important to think about the drawing technique, considering that drawing and playing are important means of communication and understanding of the emotional aspects of hospitalized children, as shown in the work of Menezes, Moré and Cruz (2008). These authors, as well as other researchers in the field, show that even being sick, children need to play and move to adapt and develop the requirements and restrictions of the hospitalization condition (Mitre \& Gomes, 2004; Motta \& Enumo, 2004; Oliveira, Dias \& Roazzi, 2003; Rice, Glasper, Keeton \& Spargo 2008).

The necessity of playing is also important and should not be eliminated when children fall ill or are hospitalized, since games play important roles, such as the ability to feel more secure in a strange environment with unfamiliar people (Azevedo, Santos, Justino, Miranda \& Simpson, 2008).

A survey of 35 hospitalized children, of both genders and between 5 and 7 years of age investigated, through drawing, the feelings and behaviors of children. The grouping of drawings and children's answers originated the analysis categories: fear, flight, guilt, sadness and distrust on the team, indicating that the surgery situation had provoked negative feelings, suggesting the need to prepare the child for hospitalization and surgical procedures as a measure of protection to child development (Crepaldi \& Hackbarth, 2002).

On the same subject and using the procedure of drawing-stories, Trinca (2003) conducted a qualitative study of clinical intervention in a hospital pediatric unit. The author studied how the drawings-stories act in the therapeutic intermediation of the psychological situation of children in pre-surgical elective surgeries.
Another study using drawings was carried out by Gabarra (2005), who investigated children between 5 and 13 years of age hospitalized as a result of chronic diseases. The objective of the author cited was to investigate the children's understanding of the origin of the diseases, treatments, hospitalization, prevention, as well as the feelings related to the illness and to the factors that influence the understanding of diseases. Other studies also used drawings with children, such as Marrach and Kahhle (2003), who investigated how children feel about the disease and the hospitalization, and Oliveira, Cariola and Pimentel (2001), a study in which the drawing was used as a measurement of anxiety for children undergoing reconstructive surgery for cleft lip and/or palate.

\section{Pre-surgical psychological preparation}

Psychological preparation for medical and surgical procedures should include two fundamental aspects: information about the details of experience to be lived and the teaching of effective coping strategies. The goal of the information is to promote the ability to handle events, anticipating them and understanding their objectives, their meaning and their purpose, besides explaining whatever is still not clear (Salmon, 2006). An accurate assessment of the child and their psychosocial conditions evaluated together with the family is recommended. It will include the level of development and their coping style; the understanding of the child and family about their medical condition and the medical procedure to be performed; previous experience of hospitalization and particularly of adverse situations; emotional, cognitive and physical symptoms; fears in general and of specific procedures and other possible health problems; and the way in which family members make decisions (Le Roy et al., 2003).

Programs of preoperative preparation can be represented by information reported, written, hospital visits, informational videos, techniques using puppets, relaxation techniques or enactment with the participation of the children playing the role of the physician or the patient (Watson \& Visram, 2003). During the preparation phase, Yamada and Bevilacqua (2005) suggest that a space be offered for the child to become familiar with the situation they will live in the surgical process as well as the opportunity to act them out as a 
theater play. Furthermore, there should be a moment for the child to ask questions (Le Roy et al., 2003).

For all age groups, the participation in recreational activities that included receiving information on medical issues increased the probability that the patient acquired a more active repertoire of behaviors in relation to the hospital. It also allowed that the hospitalization and the medical treatment could be used as an opportunity to expand the patient's behavior repertoire. These evidences were shown by Costa Jr., Coutinho and Ferreira (2006). On the importance of the information we can mention the study of Li, Lopez and Lee (2007), which, in a study with 149 patients, compared the level of anxiety the day before the surgery among patients who had diagnosis information. They concluded that knowledge may reduce anxiety.

The guided visit to the surgical center can be an important resource in preparing for surgery, in addition to the description and information about where and what will be done Crepaldi, Rabuske and Gabarra (2006). Moreover, it should also be considered the distraction techniques that are widely used, since it is difficult to pay attention to two different stimuli simultaneously. Thus, we use storybooks, fairy tales, verbal activity, and breathing exercises. According to Andraus, Minamisava and Munari (2004) people who hold information about potentially aversive or anxiogenic situations experience a greater sense of cognitive control and maintain emotional disturbance at lower levels.

Considering the importance of this subject, this paper aims to investigate the effects of pre-surgical psychological preparation on stress levels in children undergoing elective surgery according to two different procedures for preparation, assessed through the verbal report on the content of the drawings.

\section{Method}

\section{Participants}

Thirty children (15 boys and 15 girls) aged between 6 and 12 years, hospitalized in a children's hospital for small elective surgery (inguinal and umbilical hernia, tonsillectomy, adenoidectomy, and circumcision) participated in this research. These were divided into 2 groups of 15 (G1 and G2), according to the type of preparation for surgery and trying to match them with another in the other group according to age, sex and type of surgery. Inclusion criteria were: having indication for elective surgery, not having serious organic impairments, having a good prognosis, not being at risk of dying, being accompanied by a parent or guardian.

\section{Instruments}

The design and the stories are made up in a universal language appreciated by children, and that are independent of age, gender, social class or cognitive level. Drawing-story: it is a technical resource for addressing mental life that conquered, over 30 years of existence, a place of prominence as a working tool of the clinical psychologist (Trinca, 2003). Thus, it selected as a tool for data collection for this research.

\section{Procedure}

The research followed the rules of Resolution 196/96 of the National Health Council. The project was approved by the Ethics Committee of the Universidade Federal de Santa Catarina, under the consolidated no 056/07, as well as by the Ethics Committee of the University responsible for the hospital where the research was conducted, under a consolidated number 079/07.

After the authorization of the hospital, the researcher had free access to it, as well as the surgical map of the institution, that is, the scheduling of surgeries in table form, which contained the name and age of the patient, type of surgery and health insurance by which it would be held. Thus, the surgeries with defined date and time indicated to the researcher periods and times that she should be in the hospital. Before data collection, the responsible for the institution wrote an official a permit to conduct the research on site, through a Free and Informed Consent Form.

By invitation and demonstration of interest of parents and children to participate in the study, the responsible was required to sign the Free and Informed Consent Form.

The research was conducted in three stages. Step 1: The child received the following statement: "I'll tell 
you a story called The little Elephant at the Hospital. Pay close attention to the story because then I'll askyou to draw the story of the little elephant, but before this, pay close attention to memorize the story". Then the child was asked to draw the story of the little elephant. After finishing the drawing, we looked into what had been drawn. Step 2: Psychological pre-surgical preparation: In G1 (Program 1), the child received verbal information individually on the type of surgery they would be submitted to. The information consisted of telling the child all the stages through which they would pass in surgery. In G2 (Program 2), the child received information individually, from the use of the pre-surgical preparation kit, handling them and using them as it desired. The information has been given to the child as it has been playing with a doll from the kit. Each program had a maximum duration of 30 minutes. Step 3: The child received the statement: "I'll tell you again a story called The little elephant in the hospital after surgery. The story is a bit different from the first one. Pay close attention to the story because afterwards I'm going to ask you to draw the second story of the little elephant, but before that, pay attention to memorize the story". Then the same procedure was used as in Step 1.

\section{Data analysis}

For the analysis of the material we used techniques of content analysis (Bardin, 1993), which was divided into three phases: pre-analysis, analysis and processing of results and interpretation. For this study, we adapted the system of categories produced by Crepaldi and Hackbarth (2002). First, a single system of categories was used for the two groups (pre and post-test).

Secondly, the reports were divided according to the type of preparation ( $\mathrm{G} 1$ and $\mathrm{G} 2$ ) and to the differences met in pre and post-test. The category system used was submitted to experienced judges by randomly selecting 40 sentences that included at least one sentence to represent each category. After the suggested reformulations, phrases were forwarded to the judges to ensure the reliability of the system. The calculation of agreement between the judges was $82.5 \%$. Chart 1 below presents the system of categories,

\section{Results}

\section{The verbal reports by category}

The category fear occurred in 19 participants in the period prior to the preparation, with a decrease of its occurrence to 10 children in the later period. Fear decreased after the preparation, independently of which preparation had been performed, but it still occurred. "I'm like afraid of risking life ... and of something going wrong, and I do not wake up anymore". There were no significant differences in the children reports between prior and following moments to the preparation in relation to the category Escape. "The elephant is not going to the hospital, he'll run away and no one will find him anymore ... it will not have it".

The category happiness appeared in 11 children in the moments leading up to preparation, and increased to 15 children after the preparation in both groups. "I'm very happy because my grandmother said that now l'll really become a little man" (Postectomy).

The category guilt appeared in only five children in the period preceding the preparation. In the period subsequent to the preparation there was a decrease of its occurrence to only three children. "He (the elephant) is in hot water ... because his mother told him not to go far away... he went ... broke his leg and now he has to operate ... shame on him...."

The category doubt occurred in half of the children in the period leading up to surgery, with a decrease of its occurrence to only five children. Similarly, after preparation, the kids still had questions, and they were related to: when they would be able to eat, if they would feel pain, the duration of surgery and who would watch the surgery. "The only thing I wanted to know is how this hernia surgery is done... and if there are many children who go through the same thing...."

The category anxiety occurred in more than half of the children, with a decrease to only two children. After preparation, although there was a decrease in anxiety, the children's reports remained the same. "The little elephant is thinking now, nervous ... worried and confused about the surgery he will have."

The category sadness occurred in more than half of children and decreased substantially to only two children. After preparation, only two children 
Chart 1

Definition of categories about the drawings

\begin{tabular}{|c|c|}
\hline Categories & Definition \\
\hline Fear & $\begin{array}{l}\text { Reports on situations considered threatening. This may translate into hidden ideas and thoughts, seized by a feeling } \\
\text { of terror that children can draw or verbalize. It may include fears of a real situation (fear of suffering, arising from } \\
\text { procedures performed in the hospital, being afraid of needles, fear of taking I.V. saline); it involves some experience } \\
\text { (fear of losing the ability to climb trees, not being able to carry weight anymore), or other vague feelings of fear, such } \\
\text { as those arising from fantasies (fear of being in a dark room). }\end{array}$ \\
\hline Escape & $\begin{array}{l}\text { Reports of behaviors that children have to get rid of the situation that causes anxiety or of the hospital itself. They } \\
\text { behave in several ways: hiding, running away from the hospital, practicing self-harm, as "drowning in the sea" or } \\
\text { aggression towards others, "swearing the nurses." This aggressiveness is perceived as a way that the child finds to } \\
\text { express their dissatisfaction with the harsh environment in which they are, or to defend themselves from feelings of } \\
\text { insecurity and fear that put them at constant risk. }\end{array}$ \\
\hline Happiness & $\begin{array}{l}\text { Reports of behaviors that demonstrate favorable perceptions regarding the surgery, either by interest in knowing the } \\
\text { hospital, be it for the consequences of the surgery, which will provide improvement in relation to the problem, or } \\
\text { possible consequences, such as being allowed to have ice cream, or even getting a gift in exchange (bargaining). }\end{array}$ \\
\hline Guilt & $\begin{array}{l}\text { Reports of feelings that children have when they believe they have behaved improperly. In this case the disease is } \\
\text { seen as a punishment. It indicates that the children showed behaviors that upset their parents somehow before } \\
\text { hospitalization. }\end{array}$ \\
\hline Doubt & $\begin{array}{l}\text { Reports that show curiosity expressed through inquiries before the unknown. They may include uncertainties } \\
\text { regarding the problem, the procedure, the frequency of similar surgeries and the post-surgical reactions. }\end{array}$ \\
\hline Anxiety & $\begin{array}{l}\text { Reports on the behaviors that children would emit before an unknown threat, which includes an internal, vague or } \\
\text { conflicting sensation. It is characterized by a diffuse and unpleasant feeling of apprehension, accompanied by } \\
\text { headache, trembling, palpitations, crying and chest tightness. This emotional state was expressed by children with } \\
\text { words such as, worried, nervous, tense and anxious. }\end{array}$ \\
\hline Sadness & $\begin{array}{l}\text { Reports that reflect a discontent child imagining that they will not be able to perform their routine activities, such as } \\
\text { playing or doing schoolwork. }\end{array}$ \\
\hline Trust & $\begin{array}{l}\text { Reports that show optimism about the surgical procedure, because of the trust in the people who have or have had } \\
\text { involvement in the hospitalization. }\end{array}$ \\
\hline $\begin{array}{l}\text { Knowledge about } \\
\text { the surgery }\end{array}$ & $\begin{array}{l}\text { Reports that express the existence of information about the surgical procedure before they occur; demonstration of } \\
\text { interest in obtaining clarification on the procedures for having come to the hospital without prior knowledge about } \\
\text { the surgery. This may include a willingness to learn, or, conversely, not to know, besides not knowing. }\end{array}$ \\
\hline $\begin{array}{l}\text { Explanation about } \\
\text { the surgery }\end{array}$ & $\begin{array}{l}\text { Reports regarding children's perceptions of the surgery before it actually takes place, and after receiving explanations, } \\
\text { as well as the ways of feeling and acting of the children in relation to them. }\end{array}$ \\
\hline Positive reaction & $\begin{array}{l}\text { Favorable reports on the perceptions that children have after the preparation for surgery, about the hospital, } \\
\text { hospitalization and the surgical procedure itself and its consequences, such as pain, recovery and the presence of the } \\
\text { support network. }\end{array}$ \\
\hline
\end{tabular}

considered themselves sad. "It is very sad, because it will have to go to the hospital ... . I dunno ... . It's a sign of disease. The elephant may not be the same again".

The category denial occurred in five children, and after preparation it did not occur. It can be said that denial decreased in both groups. The denial manifested itself in the belief that the surgery would not be necessary. "He is not even going to operate ... the doctor will say that he doesn't need surgery anymore ...."

The category trust was highlighted by four children before the preparation and directed this trust to God and to the doctor. No child mentioned trust after that. "He liked the doctor a lot, he did a lot of cool things with him... he even told the doctor a secret, that I will not tell you because it was secret, and not even I know it, because it was a secret only of both of them... and the doctor was really good, he was going to make everything all right with him..."

The category Knowledge about the surgery included the information that children had and that they still wanted to have about their surgery. Over half of the children wanted information about the surgery and showed to be very interested. Only five children reported that they did not want to know, and eight 
children said that they had no information, and that they had no prior knowledge about the procedure they would be submitted to. "I do not want to know anything, and when my mom tries to talk I cover my ears and I pretend it's not with me.... It's worth mentioning that this category occurred only in the drawings made at the time prior to the psychological preparation.

After receiving the information, more than half of the children had good reactions (positive reactions) in relation to what they had known, whether in relation to the surgery itself, recovery, pain, bandages, anesthesia and to the support network. In general, they made colorful designs representing the elephant back home, recovered, in good health and happy to be well after surgery. "Now he only has to recover to go back home, but it's fast, he's already good and soon his pain will pass and he will even be able to play..." You can tell by the analysis of verbal reports, there was slight increase in the effectiveness of $\mathrm{G} 2$ comparing to $\mathrm{G} 1$, in the period after preparation.

\section{Discussion}

It was found that both preparation programs were effective in reducing preoperative stress regardless of the program used. Both techniques used are mentioned in the literature as effective in preparing children (Bess d'Alcantara, 2008; Moix, 1996; Watson \& Visram, 2003; Yamada \& Bevilacqua, 2005), which was also verified in this study, in both preparatory programs, which are primarily based on the information, whether narrated or experienced.

Melamed and Siegel (1975) mention that the preparation was the most effective procedure to reduce stress when compared to other procedures, such as the presence of the mother exclusively, because besides the presence of parents during hospitalization and its undeniable importance in medical treatments, they also require monitoring to properly inform the child. This was observed in this study, that is, the mother's presence alone did not guarantee good information and lower anxiety.

It can be argued that the lack of information actually causes fear, anxiety, depression, besides stress and anxiety, since before receiving the preparation, 372 children expressed in their drawings considerable indications of the different emotional states evaluated and, after the preparation, there was a decrease of these indications. This is corroborated by Costa Jr et al. (2006) in stating that, in all age groups, the participation in recreational activities that included the knowledge of information on medical topics increased the likelihood that the patient acquired a more active behavior repertoire in relation to the hospital environment.

The results also go together with those obtained by Kiyohara et al. (2004) and Li, Lopez and Lee (2007). The latter authors reported the importance of the information, since in a study with 149 patients, whose aim was to compare the degree of anxiety on the day prior to the surgery with patients who had information about their diagnosis, surgery and anesthesia, concluded that knowledge about the surgery to be performed can reduce the state of anxiety.

It is considered acceptable that even after the preparation the child still feels afraid, but that must be faced because of the conditions the preparation has provided. In relation to anxiety, it can happen even after preparation. However, it was observed that in G2 this anxiety happened more by the desire to return home and get better than the medical condition itself.

It can be seen that the children from $\mathrm{G} 2$ reported the presence of happiness, which did not happen in G1. It was observed that children had fewer feelings of inferiority, insecurity and abandonment in G2, because they made drawings where the elephant was in the company of his mother. This can be considered positive and indicates that the children were able to face the situation, seeing it in a positive way to improve health, supposedly, as soon as that the preparation of G2 achieved better results.

\section{Final Considerations}

The results of this study cannot be considered conclusive, since, in addition to the small sample size, it did not aim at the control of the variables. On the other hand, the two groups started from a period prior to the preparation rather homogeneous, a fact that allowed to evaluate the subsequent time, with the same starting point, providing a better outcome in the evaluation of the difference that exists between the pre and post-test, according to two distinct programs the 
preoperative psychological preparation. Therefore, these results can be considered good indicators for more accurate studies.

The practical implications of the results of this study emphasize the importance of preparing the child for the different phases of a surgical procedure, ranging from the decision to do the surgery until the results after its completion.

A child that can follow what is going on with them, obviously considering each age group, can calm down and become more collaborative with the post-surgical procedures and the need for surgery, even if it leaves marks. The effects of hospitalization for the surgery can be mitigated by simple procedures. If the surgery is an emergency and there is no possibility of carrying out the psychological preparation, it is important to intervene similarly after surgery, turning to the information about the procedure and clarifying on what was done.

The psychologist may promote intervention strategies for both the child and the family and staff, advising on the need to support and shelter the child, so as to minimize the negative feelings and to make the child feel protected.

The work with drawings in hospitalization besides playing ludic role, it also acts as a resource for psychological evaluation, showing itself as an effective measurement instrument and human communication, not only in cases of hospitalization, but in different contexts. In this research, by drawing the children verbalized and expressed their feelings about the situation experienced, not to mention the very act of drawing, which, by itself, has acted as resource preparation. However, rigorous empirical studies that consider the peculiarities of the sick child, their evolutionary stage, their emotional, family and social conditions are needed.

\section{Referências}

Andraus, L. M. S., Minamisava, R. F., \& Munari, D. B. (2004). Comunicação com a criança no pré-operatório. Pediatria Moderna, 40(6), 242-246.

Azevedo, D. M., Santos, J. J. S., Justino, M. A. R., Miranda, F. A. N., \& Simpson, C. A. (2008). O brincar enquanto instrumento terapêutico: opinião dos acompanhantes. Revista Eletrônica de Enfermagem, 10(1), 145-151. Recuperado em maio 27,2008, disponível em <http://www.fen.ufg.br/ revista/v10/n1/v10n1a13.htm>.

Bardin, L. (1993). L'analyse de contenu. Paris: PUF.

Bess d'Alcantara, E. (2008). Criança hospitalizada: o impacto do ambiente hospitalar no seu equilíbrio emocional. Revista Virtual de Psicologia Hospitalar e da Saúde, 3(6), 38-55.

Broering, C. V.,\&Crepaldi, M. A. (2008). Preparação psicológica para a cirurgia em pediatria: importância, técnicas e limitações. Paidéia, 18(39), 61-72.

Costa Jr., A. L., Coutinho, S. M. G., \& Ferreira, R. S. (2006). Recreação planejada em sala de espera de uma unidade pediátrica: efeitos comportamentais. Paidéia, 16(33), 111-118.

Crepaldi, M. A., \& Hackbarth, I. D. (2002). Aspectos psicológicos de crianças hospitalizadas em situação pré-cirúrgica. Temas em Psicologia da SBP, 10(2), 99-112.

Crepaldi, M. A., Rabuske, M. M., \& Gabarra, L. M. (2006). Modalidades de atuação do psicólogo em psicologia pediátrica. In M. A. Crepaldi, B. M. Linhares \& G. B. Perosa (Orgs.), Temas em psicologia pediátrica. São Paulo: Casa do Psicólogo.

Faquinello, P., Higarashi, I. H., \& Marcon, S. S. (2007). O atendimento humanizado em unidade pediátrica: percepção do acompanhante da criança hospitalizada. Texto e Contexto: Enfermagem, 16(4), 619-616.

Gabarra, L. M. (2005). Crianças hospitalizadas com doenças crônicas: a compreensão da doença (Dissertação de mestrado não-publicada). Programa de Pós-Graduação em Psicologia, Universidade Federal de Santa Catarina.

Gabarra, L. M., \& Crepaldi, M. A. (2011). A comunicação médico-paciente pediátrico-família na perspectiva da criança. Psicologia Argumento, 29(65), 209-218.

Kiyohara, L. Y., Kayano, L. K., Oliveira, L. M., Yamamoto, M. U., Inagaki, M. M., Ogawa, N. Y., et al. (2004). Surgery information reduces anxiety in the pre-operative period. Revista do Hospital das Clínicas, 59(2), 51-56.

Le Roy, S., Elixson, E. M., O'Brien, P., Tong, E., Turpin, S., \& Uzark, K. (2003). Recommendations for preparing children and adolescents for invasive cardiac procederes. Circulation, 108(20), 2550-2564.

Li, H. C. W., Lopez, V., \& Lee, L. I. (2007). Psychoeducational preparation of children for surgery: The importance of parental involvement. Patient Education and Counseling, 65(1), 34-41.

Marrach, L. A. F., \& Kahhle, E. M. P. (2003). Saúde e doença: o que pensam e sentem as crianças hospitalizadas e suas mães acompanhantes. Revista Brasileira de Crescimento e Desenvolvimento Humano, 13(2), 73-84.

Melamed, B. G., \& Siegel, L. J. (1975). Reduction of anxiety in children facing hospitalization and surgery by use of filmed modelling. Journal of Consulting and Clinical Psychology, 43(4), 511-521.

Menezes, M., Moré, C. L. O. O., \& Cruz, R. M. (2008). O desenho como instrumento de medida de avaliação psicológica em crianças hospitalizadas. Avaliação Psicológica, 7(2), 189-198. 
Mitre, R. M., \& Gomes, R. (2004). A promoção do brincar no contexto da hospitalização infantil como ação de saúde. Ciência e Saúde Coletiva, 9(1), 147-154.

Moix, J. (1996). Preparación psicológica para la cirurgia en pediatria. Archivos de Pediatria, 47(4), 211-217.

Motta, A. B., \& Enumo, S. R. F. (2004). Brincar no hospital: estratégia de enfrentamento da hospitalização infantil. Psicologia em Estudo, 9(1), 19-28.

Oliveira, H. P., Cariola, T. C., \& Pimentel, M. C. M. (2001). A ansiedade infantil depois do preparo pré-operatório verbal e lúdico. Pediatria Moderna, 37(4), 0-0.

Oliveira, S. S. G., Dias, M. G. B. B., \& Roazzi, A. (2003). O lúdico e suas implicações nas estratégias de regulação das emoções em crianças hospitalizadas. Psicologia: Reflexão e Crítica, 16(1), 1-13.

Rice, M., Glasper, A., Keeton, D., \& Spargo, P. (2008). The effect of preoperative education programme on perioperative anxiety in children: An observational study. Pediatric Anesthesia, 18(5), 426-430.

Salmon, K. (2006). Preparing young children for medical procedures: Taking account of memory. Journal of Pediatric Psychology, 31(8), 859-861.
Trinca, A. M. T. (2003). A intervenção terapêutica breve e a précirurgia infantil:o procedimento de desenhos-estórias como instrumento de intermediação terapêutica. São Paulo:Vetor.

Uman, L. S., Chambers, C. T., McGrath, P. J., \& Kisely, S. (2008). A systematic review of randomized controlled trials examining psychological interventions for needle-related procedural pain and distress in children and adolescents: An abbreviated Cochrane Review. Journal of Pediatric Psychology, 33(8), 842-854.

Watson, A. T., \& Visram, A. (2003). Children's preoperative anxiety and postoperative behaviour. Paediatric Anaesthesia, 13(3), 188-204.

Yamada, M. O., \& Bevilacqua, M. C. (2005). O papel do psicólogo no programa de implante coclear do Hospital de Reabilitação de Anomalias Craniofaciais. Estudos de Psicologia (Campinas), 22(3), 255-262. doi: 10.1590/S0103-16 6X2005000300004.

Received on: 26/7/2011

Final version on: 26/3/2012

Approved on: 7/5/2012 